\title{
BMJ Open Medical students' knowledge, attitudes and perceptions towards contraceptive use and counselling: a cross-sectional survey in Maharashtra, India
}

\author{
Sara Hogmark, ${ }^{1,2}$ Marie Klingberg-Allvin, ${ }^{2,3}$ Kristina Gemzell-Danielsson, ${ }^{4}$ \\ Hannes Ohlsson, ${ }^{2}$ Birgitta Essén ${ }^{2}$
}

To cite: Hogmark S, Klingberg-Allvin M, GemzellDanielsson $\mathrm{K}$, et al. Medical students' knowledge, attitudes and perceptions towards contraceptive use and counselling: a crosssectional survey in Maharashtra, India. BMJ Open 2013;3:e003739. doi:10.1136/bmjopen-2013003739

- Prepublication history for this paper is available online. To view these files please visit the journal online (http://dx.doi.org/10.1136/ bmjopen-2013-003739).

Received 5 August 2013 Revised 5 October 2013 Accepted 9 October 2013

\section{CrossMark}

For numbered affiliations see end of article.

Correspondence to Dr Sara Hogmark; sara.hogmark@Itdalarna.se

\section{ABSTRACT}

Objectives: This study aimed to investigate the knowledge, attitudes and perceptions towards contraceptive use and counselling among medical students in Maharashtra, India.

Setting: Considerable global maternal mortality and morbidity could be avoided through the use of effective contraception. In India, contraception services are frequently unavailable or there are obstacles to obtaining modern, reversible contraceptives.

Participants: A cross-sectional descriptive study using a self-administered questionnaire was conducted among 1996 medical students in their fifth year of study at 27 medical colleges in the state of Maharashtra, India. Descriptive and analytical statistics interpreted the survey instrument and significant results were presented with $95 \% \mathrm{Cl}$.

Results: Respondents expressed a desire to provide contraceptive services. A few students had experienced training in abortion care. There were misconceptions about modern contraceptive methods and the impact of sex education. Attitudes towards contraception were mainly positive, premarital counselling was supported and the influence of traditional values and negative provider attitudes on services was recognised. Gender, area of upbringing and type of medical college did not change the results.

Conclusions: Despite mostly positive attitudes towards modern contraceptives, sex education and family planning counselling, medical students in Maharashtra have misconceptions about modern methods of contraception. Preservice and in-service training in contraceptive counselling should be implemented in order to increase women's access to evidence-based maternal healthcare services.

\section{INTRODUCTION}

Contraceptive use is an effective primary prevention strategy for reducing maternal mortality. ${ }^{1}$ It has been estimated that the use of effective contraception could avert $90 \%$ of abortion-related and more than 20\% of

\section{Strengths and limitations of this study}

- This study contributes important evidence that may be used to revise basic medical education in contraceptive counselling and thus reduces maternal mortality related to unintended pregnancies in India.

- An important limitation with this study is the non-probability sampling technique applied which might reduce the external validity.

- The large sample size and the inclusion of medical students from public and private medical schools in urban and semiurban settings strengthen the generalisability.

obstetric-related mortality globally. ${ }^{2}$ Abortion incidence is inversely associated with the level of contraceptive use, especially where the fertility rates are stable. ${ }^{3}$ In addition, comprehensive sex education has the potential to prevent unintended pregnancies that lead to unsafe abortions. ${ }^{4}$ In order to meet the increasing demand for contraceptives and to ensure the sexual and reproductive health and rights of women, including the right to planned parenthood, intensified efforts are urgently needed. ${ }^{5}$

India accounts for $20 \%$ of maternal deaths worldwide. ${ }^{6}$ Despite the fact that induced abortion has been legal in India since 1971, most of the approximately 6.7 million annually induced abortions are performed in an unsafe manner. ${ }^{78}$ Moreover, a recent study concluded that $70 \%$ of all Indian women who have an abortion do not use postabortion contraception. ${ }^{9}$ The unmet need for modern contraceptives is $22 \%$ in the cities and higher in rural areas. Female sterilisation is the most common contraceptive practice and accounts for $75 \%$ of all methods used. ${ }^{10}$ The use of reversible, modern methods in order to 
postpone the birth of a first child or for spacing births is infrequent. ${ }^{11}$

Some of the barriers that impede women's access to contraception are healthcare providers who are inadequately trained, insufficient in number and poorly supervised. ${ }^{12}$ Studies have shown that improving the quality of care increases and sustains contraceptive use by women. ${ }^{13}$ Providers need adequate knowledge of contraceptive methods and training in counselling skills in order to provide reliable information to women. ${ }^{14}$ Despite the availability of effective methods of contraception in India, many pregnancies remain unintended. Considering the future role of medical students as contraceptive counsellors, little is known about their views on contraceptive methods, use or counselling. This study aimed to investigate the knowledge, attitudes and perceptions towards contraceptive use and counselling among medical students in Maharashtra, India.

\section{MATERIALS AND METHODS}

In February 2011, a cross-sectional survey was conducted using a pretested, self-administered questionnaire among medical students in their fifth year (internship) of training in the Indian state of Maharashtra. ${ }^{15}$ Of a total of 43 medical colleges in Maharashtra (5195 students), 19 are public (2200 students). A convenience sample of 27 colleges ( 8 public and 19 private) was included in the study. The total number of students eligible at the study sites was 2006 and in total 1996 students responded to the questionnaire (1423 private and 573 public colleges). All medical students at the selected institutions were asked to participate before attending a lecture in comprehensive abortion care (CAC). The lecture was organised by a non-governmental organisation within the medical education programme.

\section{Study setting}

Located in west-central India, Maharashtra is the country's second most populous state and the third largest in area. Of its 112 million inhabitants, a slight majority live in rural areas. Maharashtra's socioeconomic status, literacy rate and health infrastructure are better than the national average. ${ }^{16}$ Medical education in India is regulated by the Medical Council of India and is either public or private. Medical education consists of 4.5 years of theoretical studies followed by 1 year of internship. According to the national medical education curriculum, the theoretical studies should cover CAC, as well as contraceptive methods and counselling. ${ }^{17}$

\section{Instrument}

The questionnaire contained three sections. Section 1 included sociodemographic characteristics such as gender, age, religion, marital status, place of birth/area of upbringing and type of college. Section 2 included questions related to perception of education and training in sexual and reproductive health, and respondents' assessment of their knowledge regarding contraceptive methods and services. Section 3 consisted of 12 statements on different aspects of contraceptive methods, services and values surrounding sexual and reproductive health. Participants were asked to circle the most appropriate alternative on a five-point Likert scale (disagree completely/disagree/neither agree nor disagree/agree/ agree completely). ${ }^{18}$

\section{Statistical analysis}

Questionnaires that contained one or more answers were included in the analysis. Statistical Package for Social Studies (SPSS) V.20.0 software was used. Descriptive statistics were applied to all sections of the questionnaire; actual numbers and proportions were calculated; and cross-tabulations with intergroup comparisons of answers were made for students of different genders, types of colleges and places of birth. The alternatives 'agree' and 'agree completely' were aggregated, as well as the alternatives 'disagree' and 'disagree completely'. Any difference with a $95 \%$ CI was regarded as significant.

\section{Ethical considerations}

The study was carried out in compliance with the principles of the World Medical Association Declaration of Helsinki. The medical students eligible for participation in the study were given oral information about the study and were informed that participation was anonymous and voluntary and that choosing not to participate would not affect their studies or future careers negatively. By filling in the questionnaire, written consent to participation was given. Permission to conduct the survey in connection with the training programme was obtained from the principal at each college.

\section{RESULTS}

A total of 1996 medical students participated in the study (response rate 99\%; 1996/2006). The demographic characteristics of the students are outlined in table 1. Since the students were homogeneous in terms of age, religion and marital status, the variables remaining for intergroup comparisons were gender $(56.8 \%$ male and $43.1 \%$ female), place of birth $(72.3 \%$ urban and $25.5 \%$ rural $)$ and type of college (71.3\% private and $28.7 \%$ public).

Table 2 shows the students' perception of education and training in sexual and reproductive health, as well as the respondents' assessment of their knowledge regarding contraceptive methods and services. Most of the students thought that the topic of reproductive health, including contraceptive methods, had been adequately covered in their curriculum. A majority considered their theoretical knowledge in sexual and reproductive health to be fair or good. A large proportion reported having had no clinical practice in abortion care services during their training. A comparison between students from private and public colleges revealed no significant differences. 
Table 1 Demographics of medical students in Maharashtra, India, 2011 ( $n=1996)$.

\begin{tabular}{|c|c|c|}
\hline Variable & $\mathbf{n}$ & Per cent \\
\hline \multicolumn{3}{|l|}{ Age } \\
\hline $20-24$ & 1886 & 94.4 \\
\hline 25 and above & 98 & 5 \\
\hline Data missing & 12 & 0.6 \\
\hline \multicolumn{3}{|l|}{ Gender } \\
\hline Female & 860 & 43.1 \\
\hline Male & 1134 & 56.8 \\
\hline Data missing & 2 & 0.1 \\
\hline \multicolumn{3}{|c|}{ Place of birth/upbringing } \\
\hline Rural & 508 & 25.5 \\
\hline Urban & 1444 & 72.3 \\
\hline Data missing & 44 & 2.2 \\
\hline \multicolumn{3}{|l|}{ Religion } \\
\hline Hindu & 1747 & 87.7 \\
\hline Muslim & 97 & 4.9 \\
\hline Christian & 17 & 0.9 \\
\hline Other & 133 & 6.7 \\
\hline Data missing & 2 & 0.1 \\
\hline \multicolumn{3}{|l|}{ Marital status } \\
\hline Single & 1970 & 98.7 \\
\hline Married & 22 & 1.1 \\
\hline Data missing & 4 & 0.2 \\
\hline \multicolumn{3}{|l|}{ Type of college } \\
\hline Private & 1402 & 71.3 \\
\hline Public & 556 & 28.7 \\
\hline
\end{tabular}

With regard to contraceptive counselling, $74 \%$ believed it should be given individually and not in a group. A majority of the respondents $(67.2 \%)$ thought doctors should be the ones to provide contraception to patients, while $27.1 \%$ considered health workers to be the most appropriate counsellors. A few students chose other alternatives (nurse 3\%, other 1.6\% and missing $1.1 \%)$. A majority (95.1\%) indicated that they would like to have responsibility for providing information on contraception as future doctors. Regarding the use of oral contraceptives, $88.5 \%$ of the students stated that they should be taken every day. Some students $(5.8 \%)$ thought they were to be taken after intercourse or once a month $(3.4 \%)$. A cross-sectional analysis of answers given by students from rural versus urban places of birth revealed no significant differences with regard to these results. However, those from private colleges preferred individual contraceptive counselling over group counselling (private college students $78.2 \%$, 95\% CI $75.9 \%$ to $80.3 \%$; public college students $70.6 \%, 95 \%$ CI $66.6 \%$ to $74.4 \%)$. Also, female students were more supportive of individual counselling than male students (females $80.2 \%, 95 \%$ CI $77.4 \%$ to $82.9 \%$; males $72.8 \%$, $95 \%$ CI $70.1 \%$ to $75.4 \%$ ). Females also expressed a greater interest in having responsibility for providing contraceptive information as future doctors than males (females $98.2 \%, 95 \%$ CI $96.8 \%$ to $98.8 \%$; males $95.3 \%$ CI $93.8 \%$ to $96.4 \%$ ). Moreover, the female students were better informed on the daily intake of contraceptive pills than the male students (females $93.3 \%, 95 \%$ CI $91.5 \%$ to $94.9 \%$; males $88.8 \%$, $95 \%$ CI $86.8 \%$ to $90.6 \%$ ).

The knowledge, attitudes and perceptions of medical students towards contraceptive methods, services and values surrounding sexual and reproductive health are shown in table 3. A cross-sectional analysis comparing students from public and private colleges indicated a

Table 2 Perceptions of education and training in sexual and reproductive health among medical students $(n=1996)$ from private $(n=1402)$ and public colleges $(n=556)$ in Maharashtra, India, 2011

\begin{tabular}{|c|c|c|c|}
\hline Variable & All $n(\%)$ & Private $\mathrm{n}(\%)$ & Public $n(\%)$ \\
\hline \multicolumn{4}{|c|}{ Was sexual and reproductive health included in your curriculum? } \\
\hline Not at all & $27(1.4)$ & $17(1.2)$ & $10(1.8)$ \\
\hline Somewhat & 468 (23.4) & $352(25.0)$ & $116(20.6)$ \\
\hline Sufficiently & $1475(73.9)$ & $1039(73.8)$ & $436(77.6)$ \\
\hline Data missing & $26(1.3)$ & & \\
\hline \multicolumn{4}{|c|}{ Have contraceptive methods been taught in your programme? } \\
\hline Not at all & $16(0.8)$ & $4(0.3)$ & $12(2.1)$ \\
\hline Somewhat & $199(10.0)$ & $143(10.1)$ & $56(10.0)$ \\
\hline Sufficiently & $1759(88.1)$ & 1265 (89.6) & $494(87.9)$ \\
\hline Data missing & $22(1.1)$ & & \\
\hline \multicolumn{4}{|c|}{ How do you assess your theoretical knowledge of sexual and reproductive health? } \\
\hline Poor & $30(1.5)$ & $24(1.7)$ & $6(1.1)$ \\
\hline Fair & $552(27.7)$ & $381(27.0)$ & $171(30.9)$ \\
\hline Good & $1122(56.2)$ & $815(57.8)$ & $307(55.4)$ \\
\hline Very good & $260(13.0)$ & $190(13.5)$ & 70 (12.6) \\
\hline Data missing & $32(1.6)$ & & \\
\hline \multicolumn{4}{|c|}{ Have you had clinical practice in abortion care services during your training? } \\
\hline Yes & 268 (13.4) & $196(14.1)$ & $72(13.0)$ \\
\hline No & $1678(84.1)$ & $1196(85.9)$ & $482(87.0)$ \\
\hline Data missing & $50(2.5)$ & & \\
\hline
\end{tabular}


Table 3 Knowledge, attitudes and perceptions on contraception among medical students ( $\mathrm{n}=1996)$ in Maharashtra, India, 2011

\begin{tabular}{|c|c|c|c|c|c|c|c|}
\hline Statement & $\begin{array}{l}\text { Disagree } \\
\text { completely }\end{array}$ & Disagree & Neither & Agree & $\begin{array}{l}\text { Agree } \\
\text { completely }\end{array}$ & Missing & Statement \\
\hline \multirow[t]{2}{*}{ Contraceptive pills might cause cancer } & $\mathrm{n}$ & 118 & 267 & 170 & 1126 & 304 & 11 \\
\hline & $\%$ & 5.9 & 13.4 & 8.5 & 56.1 & 15.2 & 0.6 \\
\hline \multirow[t]{2}{*}{ Contraceptive pills can cause infertility } & $\mathrm{n}$ & 526 & 857 & 227 & 349 & 25 & 12 \\
\hline & $\%$ & 26.4 & 42.9 & 11.4 & 17.5 & 1.3 & 0.6 \\
\hline \multirow[t]{2}{*}{ Contraceptive pills are inconvenient to use } & $\mathrm{n}$ & 608 & 855 & 236 & 249 & 38 & 10 \\
\hline & $\%$ & 30.5 & 42.8 & 11.8 & 12.5 & 1.9 & 0.5 \\
\hline \multirow{2}{*}{$\begin{array}{l}\text { Emergency contraceptive pills can be used } \\
\text { several times a month }\end{array}$} & $n$ & 972 & 630 & 115 & 227 & 37 & 15 \\
\hline & $\%$ & 48.7 & 31.6 & 5.8 & 11.4 & 1.9 & 0.8 \\
\hline \multirow{2}{*}{$\begin{array}{l}\text { Condoms protect against sexually } \\
\text { transmitted diseases/HIV }\end{array}$} & $n$ & 30 & 19 & 22 & 556 & 1361 & 8 \\
\hline & $\%$ & 1.5 & 1 & 1.1 & 27.9 & 68.2 & 0.4 \\
\hline \multirow{2}{*}{$\begin{array}{l}\text { Traditional contraceptive methods (safe } \\
\text { periods, withdrawal) are the best }\end{array}$} & $n$ & 647 & 913 & 166 & 190 & 69 & 11 \\
\hline & $\%$ & 32.4 & 45.7 & 8.3 & 9.5 & 3.5 & 0.6 \\
\hline \multirow{2}{*}{$\begin{array}{l}\text { Contraceptive information should only be } \\
\text { for married couples }\end{array}$} & $n$ & 1305 & 566 & 57 & 41 & 20 & 7 \\
\hline & $\%$ & 65.4 & 28.4 & 2.9 & 2.1 & 1 & 0.4 \\
\hline \multirow{2}{*}{$\begin{array}{l}\text { Doctors working in abortion services have } \\
\text { friendly attitudes towards unmarried women }\end{array}$} & $n$ & 166 & 346 & 559 & 695 & 215 & 15 \\
\hline & $\%$ & 8.3 & 17.3 & 28 & 34.8 & 10.8 & 0.8 \\
\hline \multirow{2}{*}{$\begin{array}{l}\text { Married couples are shy to talk about } \\
\text { contraception with each other }\end{array}$} & $n$ & 150 & 629 & 423 & 720 & 64 & 10 \\
\hline & $\%$ & 7.5 & 31.5 & 21.2 & 36.1 & 3.2 & 0.5 \\
\hline \multirow{2}{*}{$\begin{array}{l}\text { Women feel confident discussing } \\
\text { contraception with doctors }\end{array}$} & $n$ & 86 & 654 & 445 & 696 & 105 & 10 \\
\hline & $\%$ & 4.3 & 32.8 & 22.3 & 34.9 & 5.3 & 0.5 \\
\hline \multirow{2}{*}{$\begin{array}{l}\text { Traditional values are barriers for sex } \\
\text { education in India }\end{array}$} & $n$ & 72 & 137 & 116 & 939 & 722 & 10 \\
\hline & $\%$ & 3.6 & 6.9 & 5.8 & 47 & 36.2 & 0.5 \\
\hline \multirow{2}{*}{$\begin{array}{l}\text { Sex education encourages unmarried } \\
\text { people to have sex }\end{array}$} & $n$ & 536 & 824 & 329 & 232 & 68 & 7 \\
\hline & $\%$ & 26.9 & 41.3 & 16.5 & 11.6 & 3.4 & 0.4 \\
\hline
\end{tabular}

difference of opinion regarding the statement "Doctors working in abortion service have friendly attitudes towards unmarried women." Fewer students from private colleges agreed or agreed completely compared with students from public colleges (private college students $43.8 \%, 95 \%$ CI $41.8 \%$ to $46.4 \%$; public college students $51.2 \%, 95 \%$ CI $47.0 \%$ to $51.4 \%$ ).

Table 4 summarises the significant differences in perceptions found among students based on their place of birth (urban or rural): to a greater extent, students with an urban place of birth agreed with the statement "Contraceptive pills might cause cancer" (urban $74.1 \%$, $95 \%$ CI $71.8 \%$ to $76.4 \%$; rural $66.4 \%$, $95 \%$ CI $62.2 \%$ to $70.5 \%$ ); a larger proportion of students from a rural background agreed with the statement "Doctors working in abortion service have friendly attitudes towards unmarried women" (rural 55.9\%, CI 95\% 51.6\% to 60.2\%; urban $42.4 \%$, $95 \%$ CI $39.8 \%$ to $45.0 \%$ ); and it was more common for students with a rural place of birth to agree with the statement "Sex education encourages unmarried people to have sex" (rural 20.2\%, CI 95\%, $16.9 \%$ to $24.0 \%$; urban $13.2 \%, 95 \%$ CI $11.5 \%$ to $15.1 \%$ ).

Table 5 compares male and female medical students' knowledge, attitudes and perceptions towards contraception. More female students agreed or agreed completely that contraceptive pills might cause cancer. Male students tended to believe that emergency contraceptive pills may be used several times a month. Male and female students largely agreed or agreed completely that condoms protect against sexually transmitted diseases (STD) and HIV, although female students were significantly more supportive of their use. One in 5 male

Table 4 Place of birth in relation to knowledge, attitudes and perceptions on contraception

\begin{tabular}{|c|c|c|c|}
\hline Statement & $\begin{array}{l}\text { Place } \\
\text { of birth }\end{array}$ & $\begin{array}{l}\text { Agree or agree } \\
\text { completely } n^{\star}(\%)\end{array}$ & $95 \% \mathrm{Cl}$ \\
\hline \multirow[t]{2}{*}{ Contraceptive pills might cause cancer } & Rural & $344(66.4)$ & 62.2 to 70.5 \\
\hline & Urban & $1081(74.1)$ & 71.8 to 76.4 \\
\hline \multirow{2}{*}{$\begin{array}{l}\text { Doctors working in abortion services have friendly attitudes towards unmarried } \\
\text { women }\end{array}$} & Rural & 289 (55.9) & 51.5 to 60.2 \\
\hline & Urban & $617(42.4)$ & 39.8 to 45.0 \\
\hline \multirow[t]{2}{*}{ Sex education encourages unmarried people to have sex } & Rural & $105(20.2)$ & 16.9 to 24.0 \\
\hline & Urban & $193(13.2)$ & 11.5 to 15.1 \\
\hline
\end{tabular}

Summary of significant differences among medical students $(n=1996)$ in Maharashtra, India, 2011.

*Number of students does not always total 1996 due to missing answers. 
Table 5 Comparison of male and female medical interns' knowledge, attitudes and perceptions towards contraception $(\mathrm{n}=1996)$ in Maharashtra, India, 2011

\begin{tabular}{|c|c|c|c|}
\hline Statement & $\begin{array}{l}\text { Sex female (F) } \\
\text { male (M) }\end{array}$ & $\begin{array}{l}\text { Agree or agree } \\
\text { completely } n^{\star}(\%)\end{array}$ & $95 \% \mathrm{Cl}$ \\
\hline \multirow[t]{2}{*}{ Contraceptive pills might cause cancert } & $\mathrm{F}$ & $652(77.1)$ & 74.1 to 79.9 \\
\hline & M & $753(68.0)$ & 65.2 to 70.8 \\
\hline \multirow[t]{2}{*}{ Contraceptive pills can cause infertility } & $\mathrm{F}$ & $150(17.7)$ & 15.2 to 20.4 \\
\hline & M & $216(19.5)$ & 17.2 to 22.0 \\
\hline \multirow[t]{2}{*}{ Contraceptive pills are inconvenient to use } & $\mathrm{F}$ & $132(15.6)$ & 13.2 to 18.2 \\
\hline & M & $149(13.4)$ & 11.5 to 15.6 \\
\hline \multirow[t]{2}{*}{ Emergency contraceptive pills can be used several times a month } & $\mathrm{F}$ & $76(9.0)$ & 7.2 to 11.1 \\
\hline & M & $182(16.5)$ & 14.3 to 18.8 \\
\hline \multirow[t]{2}{*}{ Condoms protect against sexually transmitted diseases/HIV } & $\mathrm{F}$ & 830 (97.9) & 96.7 to 98.7 \\
\hline & M & $1056(95.3)$ & 93.9 to 96.5 \\
\hline \multirow{2}{*}{$\begin{array}{l}\text { Traditional contraceptive methods (safe periods, withdrawal) } \\
\text { are the best }\end{array}$} & $\mathrm{F}$ & $90(10.7)$ & 8.7 to 12.9 \\
\hline & M & $163(14.7)$ & 12.7 to 16.9 \\
\hline \multirow[t]{2}{*}{ Contraceptive information should only be for married couples } & $\mathrm{F}$ & $22(2.6)$ & 1.6 to 3.9 \\
\hline & M & $37(3.3)$ & 2.4 to 4.6 \\
\hline \multirow{2}{*}{$\begin{array}{l}\text { Doctors working in abortion services have friendly attitudes } \\
\text { towards }\end{array}$} & $\mathrm{F}$ & $326(38.5)$ & 35.2 to 41.9 \\
\hline & M & $569(51.4)$ & 48.4 to 54.4 \\
\hline \multicolumn{4}{|l|}{ unmarried women } \\
\hline \multirow{2}{*}{$\begin{array}{l}\text { Married couples are shy to talk about contraception with each } \\
\text { other }\end{array}$} & $\mathrm{F}$ & $311(36.7)$ & 33.5 to 40.1 \\
\hline & M & $462(41.7)$ & 38.8 to 44.7 \\
\hline \multirow[t]{2}{*}{ Women feel confident discussing contraception with doctors } & $\mathrm{F}$ & 350 (41.3) & 37.9 to 44.7 \\
\hline & M & $438(39.5)$ & 36.6 to 42.5 \\
\hline \multirow[t]{2}{*}{ Traditional values are barriers for sex education in India } & $\mathrm{F}$ & $718(84.8)$ & 82.2 to 87.1 \\
\hline & M & $920(83.0)$ & 80.6 to 85.1 \\
\hline \multirow[t]{2}{*}{ Sex education encourages unmarried people to have sex } & $\mathrm{F}$ & $88(10.4)$ & 8.4 to 12.6 \\
\hline & M & $209(18.8)$ & 16.6 to 21.3 \\
\hline
\end{tabular}

students versus 1 in 10 female students agreed or agreed completely that sex education encourages unmarried people to have sex. Among male students, $51.4 \%$ agreed or agreed completely that doctors working in abortion services have friendly attitudes towards unmarried women, compared with $38.5 \%$ among female students.

\section{DISCUSSION}

The major finding in this study is the inadequate level of training in CAC and contraceptive counselling of medical students who had already passed the theoretical part of the medical education. Our findings further suggest that even though the medical students surveyed had experienced little training in abortion care services, they expressed a clear interest in disseminating contraceptive information as future physicians. Although they had mostly positive attitudes towards contraception and premarital counselling, misconceptions about modern contraceptive methods and the impact of sex education were common.

Few respondents in our study had had any clinical experience in abortion care services; yet a majority thought the topics of sexual and reproductive health and contraceptive methods had been adequately covered in their coursework. Still, nearly 1 in 5 interns falsely believed that contraceptive pills can cause infertility and 1 in 10 did not know that contraceptive pills are to be taken on a daily basis. More females than males were unaware that emergency contraceptive pills may be used several times a month. A majority of males and females perceived that contraceptive pills might cause cancer, although females were more likely to agree on this. Recent studies indicate that family planning training during residency improves future physicians' proficiency in contraceptive counselling. ${ }^{19}$

Our findings did not reveal any differences in self-rated or theoretical knowledge between public and private college students. The background factor that had the greatest influence on knowledge was gender. Female students were better informed about the utilisation of oral contraceptives and the protection that condoms offer against STD/HIV. They also reported that sex education does not encourage unmarried people to have sex. Regardless of demographic background, most of the students in our study recognised that traditional values are barriers to sex education. Few students thought that contraceptive information should only be provided to married couples, although students born in rural areas had more negative perceptions of sex education. The sociocultural norms of Indian society contribute to making sex-related issues taboo and hinder young people from seeking counselling regarding sexual health. ${ }^{20}$ Research reveals that healthcare providers often impose unnecessary barriers in dispensing contraceptives, 
including denial of a contraceptive method on the basis of age, parity, marital status or lack of parental or spousal authorisation. ${ }^{21}{ }^{22}$ One in four respondents in our study did not believe that doctors working in abortion services held positive attitudes towards unmarried women.

Although nearly all students in our survey said that they would like to assume the responsibility for contraceptive counselling in their future careers, the current shortage of providers (especially in rural areas) may require the shifting of tasks. Task sharing or shifting within family planning services is recommended by the WHO. ${ }^{23}$ The involvement of clinical officers, midwives and nurses increases access to modern contraception in low resource settings. ${ }^{24}$ The fact that one-fourth of our respondents believed that health workers, rather than physicians, were best suited to dispense contraceptive information suggests that future physicians would be willing to relegate such tasks to others.

Several studies conclude that even though abortion providers discuss contraception with their patients, it is common for patients to refuse any form of contraception following an abortion. ${ }^{25} 26$ The quality of provider counselling and patient education is important for the successful integration of new hormonal methods of contraception into clinical practice. ${ }^{27}$ Medical students need training in comprehensive sexual and reproductive health services that conforms with international human rights standards and includes respect for privacy and confidentiality, in order to provide full and accurate information to their future patients.

\section{METHODOLOGICAL CONSIDERATIONS}

One weakness is the non-probability sampling technique applied in our study, which might reduce the external validity. The large sample size and the fact that a fairly high proportion of the total number of students from private $(47.5 \%)$ and public $(26.0 \%)$ colleges from the state of Maharashtra are included strengthen the validity. However, since India is a country with large regional differences in socioeconomic and health status, our results may not be representative of all medical students in the country. On the other hand, the presence of students from public and private medical schools in urban and semiurban settings may strengthen the generalisability for Maharashtra. The method of using anonymous questionnaires is suitable for sensitive topics such as sexual and reproductive health. The fact that the questionnaire was distributed before a lecture covering the subject under investigation might influence the result. However, the students' knowledge, perceptions and attitudes reflect the content of their basic education programme. The reliability and validity of the survey are strengthened through previous testing of the instrument.

\section{CONCLUSIONS}

We have found positive and negative attitudes towards modern contraceptive methods, sex education and family planning counselling among medical students in India. There has been a willingness to offer sexual and reproductive health services to people regardless of their marital status. Still, medical students in Maharashtra have misconceptions about modern methods of contraception. Training in contraceptive counselling should be implemented in basic medical education in India in order to increase women's access to evidence-based maternal healthcare services.

\section{Author affiliations}

${ }^{1}$ Department of Obstetrics and Gynaecology, Falu County Hospital, Falun, Sweden

2Department of Women's and Children's Health (IMCH), Uppsala University, Uppsala, Sweden

${ }^{3}$ Department of Women's and Children's Health, Karolinska Institutet, School of Social and Health Science, Dalarna University, Falun, Sweden

${ }^{4}$ Department of Women's and Children's Health, Karolinska Institutet, Stockholm, Sweden

Contributors BE had the original idea of the study and developed the study protocol together with $\mathrm{HO}, \mathrm{KGD}$ and MKA, who developed the original questionnaire. $\mathrm{HO}$ entered the data and made the first analysis together with $\mathrm{SH}$ who drafted the manuscript. All authors have contributed to the writing and revision of the final version of the manuscript and approved the submitted version.

Funding The study was funded by the Faculty of Medicine, Uppsala University, Sweden, and Sida (Swedish International Development Cooperation Agency). The data collection was made under a partner-driven cooperation between Uppsala University and Ipas, New Delhi, India.

\section{Competing interests None.}

Ethics approval Oral permission was obtained from the principal of each college and also the head of the institutional board. The study has been approved by the research ethical committee at Karolinska Institutet (Dnr: 2013/415-31/4).

Provenance and peer review Not commissioned; externally peer reviewed.

Data sharing statement No additional data are available.

Open Access This is an Open Access article distributed in accordance with the Creative Commons Attribution Non Commercial (CC BY-NC 3.0) license, which permits others to distribute, remix, adapt, build upon this work noncommercially, and license their derivative works on different terms, provided the original work is properly cited and the use is non-commercial. See: http:// creativecommons.org/licenses/by-nc/3.0/

\section{REFERENCES}

1. Ahmed S, Li Q, Liu L, et al. Maternal deaths averted by contraceptive use: an analysis of 172 countries. Lancet 2012;380:111-25

2. Collumbien M, Gerressu M, Cleland J. Non-use and use of ineffective methods of contraception. In: Ezzati M, Lopez AD, Rodgers AMurray CJL. eds. Comparative quantification of health risks: Global and regional burden of disease attributable to selected major risk factors. Geneva: World Health Organization, 2004:1255-320.

3. Marston C, Cleland J. Relationships between contraception and abortion: a review of the evidence. Int Fam Plan Perspect 2003;29:6-13.

4. Oringanje $\mathrm{C}$, Meremikwu MM, Eko $\mathrm{H}$, et al. Interventions for preventing unintended pregnancies among adolescents. Cochrane Database Syst Rev 2009;(4):CD005215.

5. World Health Organization (WHO). Unsafe abortion: global and regional estimates of the incidence of unsafe abortion and associated mortality in 2008. 6th edn. Geneva: WHO, 2011.

6. World Health Organization (WHO). Trends in maternal mortality: 1990 to 2010. Geneva: WHO, 2012. 
7. Parliament of India. Medical termination of pregnancy act (MTP Act), Act No. 34 of 1971. Revised version. Delhi: Commercial Law Publishers, 2010

8. Jejeebhoy SJ, Zavier AJF, Acharya R, et al. Increasing access to safe abortion in rural Maharashtra: outcomes of a comprehensive abortion care model. New Delhi: Population Council, 2011.

9. Zavier AJ, Padmadas SS. Postabortion contraceptive use and method continuation in India. Int $J$ Gynaecol Obstet 2012;118:65-70.

10. James KS. India's demographic change: opportunities and challenges. Science 2011;333:576-80.

11. International Institute for Population Sciences (IIPS) and Macro International. National family health survey (NFHS-3), 2005-06: India. Volume 1. Mumbai: IIPS, 2007.

12. Cottingham J, Germain A, Hunt $P$. Use of human rights to meet the unmet need for family planning. Lancet 2012;380:172-80.

13. Koenig MA. The impact of quality of care on contraceptive use: evidence from longitudinal data from rural Bangladesh. Baltimore: Johns Hopkins University, 2003.

14. Curtis S, Evens E, Sambisa W. Contraceptive discontinuation and unintended pregnancy: an imperfect relationship. Int Perspect Sex Reprod Health 2011;37:58-66.

15. Klingberg-Allvin M, Van Tam V, Nga NT, et al. Ethics of justice and ethics of care. Values and attitudes among midwifery students on adolescent sexuality and abortion in Vietnam and their implications for midwifery education: a survey by questionnaire and interview. Int J Nurs Stud 2007;44:37-46.

16. Government of India, Ministry of Home Affairs. Census of India. 2011. http://www.censusindia.gov.in/default.aspx (accessed 20 Aug 2012).

17. Supe A, Burdick WP. Challenges and issues in medical education in India. Acad Med 2006;81:1076-80.
18. Spector PE. Summated rating scale construction. Sage University Paper Series on: quantitative applications in the social sciences no 82. Newbury Park, CA: Sage, 1992.

19. Steinauer JE, Turk JK, Fulton MC, et al. The benefits of family planning training: a 10-year review of the Ryan Residency Training Program. Contraception 2013;88:275--80.

20. Nath A. HIV/AIDS and Indian youth-a review of the literature (1980-2008). SAHARA J 2009;6:2-8.

21. Brown SS, Burdette L, Rodriguez P. Looking inward: provider-based barriers to contraception among teens and young adults. Contraception 2008;78:355-7.

22. Campbell M, Sahin-Hodoglugil NN, Potts M. Barriers to fertility regulation: a review of the literature. Stud Fam Plann 2006;37:87-98

23. Mbizvo MT, Chou D, Shaw D. Today's evidence, tomorrow's agenda: implementation of strategies to improve global reproductive health. Int J Gynaecol Obstet 2013;121(Suppl 1):S3-8.

24. Jacobstein R, Curtis C, Spieler J, et al. Meeting the need for modern contraception: effective solutions to a pressing global challenge. Int J Gynaecol Obstet 2013;121(Suppl 1):S9-15.

25. Jejeebhoy SJ, Kalyanwala S, Mundle S, et al. Feasibility of expanding the medication abortion provider base in India to include ayurvedic physicians and nurses. Int Perspect Sex Reprod Health 2012;38:133-42.

26. Acharya R, Kalyanwala S. Knowledge, attitudes, and practices of certified providers of medical abortion: evidence from Bihar and Maharashtra, India. Int J Gynaecol Obstet 2012;118(Suppl 1):S40-6.

27. Harper CC, Brown BA, Foster-Rosales A, et al. Hormona contraceptive method choice among young, low-income women: how important is the provider? Patient Educ Counsel 2010;81:349-54. 